УДК 94/930.2:(498.7)«1940»

DOI: https://doi.org/10.18524/2312-6825.2020.31.220052

Sergiu Cornea

ORCID.ORG/ 0000-0002-0888-5902

PhD of Historical Sciences, lecturer,

Cross-Border Faculty of the

"Dunarea de Jos" University of Galati, Romania

s_cornea@yahoo.com

\title{
THE RETREAT OF THE ROMANIAN ADMINISTRATION AND THE \\ INSTALLING OF THE SOVIET REGIME IN ISMAIL DISTRICT, AS SHOWN BY THE DOCUMENTS OF THE ROMANIAN AUTHORITIES
}

(JUNE-JULY, 1940)

\begin{abstract}
Summary
The present study re-enacts the events that took place in Ismail district within the last days under the Romanian administration, and the first weeks of the installing of the new Soviet regime.

There are documents about the reactions and approaches of the Romanian authorities regarding the retreat from Bessarabia in June 1940, the way in which local people reacted towards the events that took place quickly, the reactions of the Soviet authorities in the occupied territory, the measures taken regarding the installing of the Soviet regime.

The study is based upon the documents elaborated by the following Romanian authorities: the Royal Resident of the County Dunarea de Jos, the Third Regiment of Gendarmerie Dunarea de Jos, and the County Police Inspectorate of Dunarea de Jos.

Key words: Bessarabia, Ismail district, Romanian Administration, Soviet regime.
\end{abstract}

\section{Introduction}

As a consequence of the Soviet ultimatum of the $26^{\text {th }}$ of June 1940, Romania was forced to let go Bessarabia and Northern Bucovina. The Soviet Government acted abusively by imposing a rapid evacuation. The pressure exercised by the Soviet soldiers and their local agents created multiple issues to the people, the civil authorities, and the military troops during the retreat. At same time with the invasion of Bessarabia, the Soviet authorities took strong actions in order to re-enforce.

By means of this study on the base of the archived documents, the way in which the local population acted and reacted during the retreat of the Romanian administration from Bessarabia is elucidated. The retreat was impressively quick, the ways in which the Soviet authorities acted in the occupied territory are described, as well as the measures taken in order to install the Soviet regime.

The object of the research is the events in Ismail district that was part of the 
Dunarea de Jos County at the moment of the retreat of the Romanian administrative authorities from Bessarabia. The Romanian counties were established in 1938 (The Law of 1938) and their purpose was to reunite, as much as possible, former districts from different counties. Dunarea de Jos County was made of ten districts of the afterwar Romania: eight districts of the Former Kingdom (Braila, Covurlui, Falciu, Putna, Ramnicu-Sarat, Tecuci, Tulcea, and Tutova) and two of Bessarabia (Cahul and Ismail). The administrative center of the county was Galati where the headquarters of the Royal Resident of the county were. The ten districts included 45 subunits ( $p l a ̆ s ̧ i)$, two towns, eight urban residential townships, fourteen urban nonresidential townships, ten suburban townships, and 699 rural villages (F. 88/1940, p. 14). In 1940 the Ismail county had the following administrative and territorial structure: 4 subunits that included 62 villages out of which 5 were urban townships: Ismail, Bolgrad, Chilia Noua, Valcov and Reni (F. 88/1940, pp. 5-6).

The main method of collecting data was the analysis of the documents that the Romanian administrative and military authorities elaborated: Informative Notes of the Royal Resident of the Dunarea de Jos County, the statements of the Regional Police Inspectorate of Dunarea de Jos, and the Notes and Informative Bulletins of the Third Regiment of Gendarmerie Dunarea de Jos contained in the Fund Royal Resident of Dunarea de Jos County, the Galati District Service of the National Archives.

\section{Difficulties of the retreat of the refugees and the Romanian troops from}

\section{Bassarabia}

As a result of the Soviet ultimatum, the evacuation of Bassarabia and the Northern Bucovina by the Romanian authorities and troops and the occupation of these territories by the Soviet troops was to take place within 4 days, starting July, 28, 14:00. In order to invade these territories The Soviet Union grouped their troops of the military districts Kiev and Odessa wihtin the South Group that contained 32 infantry troops, 2 motorized infantry troops, 6 cavalry troops, 11 brigades of combat cars, 3 of a fight airplanes, 16 regiments of hard artilery, and other auxiliary units summing up 500.000 of soldiers (Caşu, 2018: 10). 
The retreat of the Romanian civil and military developped in difficult conditions, as it was accompanied by the brutal interventions of the Soviet soldiers, as well as of a part of the minority, local people that were hostile towards the Romanian people and administration. Many instituions and troops did not have enough time to evacuate because the Soviet troops did not respect the due time, and they entered earlier to occupy the territory, faster than established, and in some cases they made use of aeroforce in order to block the organized retreat of the civil and military units.

Even from the first moments of the invasion, the Soviet troops took coordinated action so that to disturb the retreat of the Romanian army and the peaceful evacuation of the population. In the morning of June, 29 in Bolgrad around 60 airplanes launched 1.3000 paratroopers that belonged to the the Soviet regiment no. 204 (Pactul, 1991: 74); they fired the machine guns towards the trains in Bolgrad station. As a result of these actions taken by the Soviet army, the Bolgrad station was blocked, and numerous trains carrying millitary stuff were seized by the Russian army helped by the people and the train station employees that sabotaged the train leaving the station. The military in the train staion werev disarmed and they wre taken the food by the minority population, supported by the Russion troops (F. 153/1939-1940, p. 66). Also, the majority of the units of Regiment 3 Gunner and Regiment 22 Artillery were disarmed, and they retreated afterwards on the bridge from Oancea (F. 133/1940, p. 95; F. 153/1939-1940, pp. 43-44, 65).

Generally, the Soviet army abusively took most of the equipment and ammunition from the units of the Romanian army, and they took event the campaign kitchens (F. 153/1939-1940, p. 67). The procedure of disarming and seizing the goods from the Romanian army was as it follows: some passing points of the Romanian army, especially the villages with minority population were taken by the Russian units that came in front of the Romanian convoys. The Soviet troops blocked the exits of the villages and challenged the Romanian troops to let their entire ammunition, equipment, and animals etc. go unless they started the fire (Șișcanu, 2007: 117-118). 
The Soviet authorities took action of intimidation of those who wanted to search refuge in Romania, as well as of those who searched to take back their goods from Bessarabia. An officer of Regiment 27 artillery, whose family remained in Ismail, asked the Soviet authorities to be reunited with his family several times. As he did not get an answer, he hired a Russian woman from Lascar Catargiu for 500 lei, and she brought his wife and 3 little children on a boat from Ismail. In Chilia Noua, 5 Romanian families were travelling towards Chilia Veche, Tulcea, were noticed by the Soviet border guards who opened the fire and killed two women on the boat, and all the others went back to Chilia Noua (F. 133/1940, p. 51). A Romanian soldier that arrived in Tulcea port on the $12^{\text {th }}$ of July told that the Soviet authorities retained his wife and children. As a reason, they invoked the fact that the Romanians did not come to Ismail to make negotiations with the Soviet border guards regarding the people exchange (F. 92/1940, p. 296).

In the informative note of the Gendarmerie of July, 201940 the following were noted: «We are also informed that a part of the people in Bessarabia asked the Soviet authorities to allow them to go to Romania, and for this purpose some of them hired carriers from Lascar Catargiu village in Tulcea to take them to the Romanian shore. The carriers waited for several days and saw no refugees coming, and then they asked a Russian guard who told them that the Soviet authorities forbade their passing...» (F. 133/1940, p. 49).

The economic units also suffered huge loss as they did not manage to evacuate their goods from Bessarabia. For instance, the ship sent by a concern to Vilcov to take 10 wagons of fish came back empty, as the Soviet authorities did not allow the fish to be taken aboard. (F. 153/1939-1940, pp. 65-66).

\section{Actions and manifestations against the Romanian military and refugees}

Coming towards the river Prut faster than agreed, the Soviet troops used instigators in order to provoke the minority population to manifestations against the Romanians, encouraged and protecting the bands and their violence (Șișcanu, 2007: 117). The report of the Regional Police Inspectorate presented to the Royal Resident on the $30^{\text {th }}$ of July 1940 , the following were mentioned: «On the occasion of the 
retreat, the Romaniana army was in big trouble, as it was attacked by the civil minority population during the retreat, they were armed with weapons taken from our troops, also with forks, cleavers, sticks, and under the protection of the Soviet army (F. 153/1939-1940, p. 43). Along July, several cases that took place during the retreat were noted by the authorities:

- The drivers of work squad no. 8, made of 20-30 tanks declared when they arrived in Cahul that they were attacked while their retreat through Tighina district by the Bulgarian, Jewish, and other minority population. Some drivers had their heads broken; their cars' windows and tires were broken and cut with knives.

- A group of the artillery fighters of the reserve of regiment 27 were attacked near the village Gaidar in Tighina by group of Bulgarians, Russians, and others, armed with iron forks, cleavers, and they disarmed them and took their equipment, leaving them bare foot and naked, and letting them escape.

- All the time during the retreat the gendarmerie was hooted and swore at by the minority people. The wagons for the evacuation were not enough as some of the authorities told the people to leave along with the animals.

- During the retreat «Lieutenant-Colonel Slav Nicu, that used to command a work battalion in Tighina, came to the gendarmerie of Oancea beaten, with his head broken, knife cuts on his chest and cheeks, unarmed and robbed by the minority bands; he escaped by leaving dressed as a beggar and came to the Regiment 68 infantry that was in Oancea».

- On the night of 5 to6 July 550 people, that were retained by the Russians, were evacuated from Reni togethr with Major Nitzu. The major declared that he was not aware what happened to the 25 Romanian officers that were in Reni (F. 92/1940, p. 406; F. 153/1939-1940, pp. 43, 44, 66).

As the informative notes of the Gendermerie noted, «the retreat of the troops and the gendermerie as well as all the authorities of Cahul and Ismail districts was prohibited by the civil very much who from the first signal of evacuation started to rob, get drunk, and in armed groups to atteck the convoys helped by the units in Bassarabia that deserted from their initial units» (F. 133/1940, p. 95). 
According to the information of the Gendarmerie, in Ismail «great disturbances took place, the people took over the shops, the red flag was flying at the mayor's, an exchange of fires between the population and the units of the river marine took place, and they defended by using machine guns. The drunken Russian population wanted to kill the refugees, the office in command of the fire men was killed» (F. 153/19391940, p. 66).

A group made of Brașoveanu - baker, Costea Terzia - broker, Ignat Zuzulin shoemaker și N. Gicolov - mechanic robbed anything that seemed to be Romanian to them, and N. Mendel took different amounts of money from the traders and owners in order to protect their fortunes from the robbers (F. 92/1940, p. 377).

In Chilia Noua, hostile manifestations took place even from the start of the evacuation of the troops and the population. Among the first leaders of the communist manifestators of Chilia Noua were identified: the doctors Rabinovici and Salakin. Some of the people that could not evacuate in time were arrested and some others were abused. The treasurer of the cooperative of the town and the teacher were carried on the streets hands tied with placards on their backs on which it was written: «their fate is uncertain». Also in Chilia Noua, the revolutionary committee arrested public guardians (F. 153/1939-1940, pp. 46, 65).

In Vilcov the people were involved in destroying the Touristic Hotel. The owner of a restaurant in the town was designated the embassy of people. In Reni incidents that led to injured and dead people took place. And the minority Bulgarians in Bolgrad attacked the Romanians. A convoy of Romanian military intervened in this conflict and re-established the order for a short period of time. (F. 153/19391940, pp. 65, 66).

The pro-Soviet provisions and the hostile attitude of some of the people of Bessarabia, especially the national minority, were mainly determined by the Soviet propaganda that was permanent and intensified during the months that preceded the taking of Bessarabia. The Romanian authorities noticed that the «Soviet propaganda by radio in Russian made the situation worse as the people in Bessarabia, especially the minority population and the poor Romanian population were instigated». By 
analysing the situation in Ismail district where the minority population «manifested by all means their sympathy to the Soviet Union»; the commandment of regiment 3 gendarmerie of Dunarea de Jos noticed that it was because of the "propaganda among them by different propaganda agents and the radio»». Apart from the alarming emissions regarding Bessarabia that they constantly broadcast, The Soviet radios also realized propaganda emissions. As a result, on the night of 24 to 25 November 1939, the radio of Tiraspol transmitted an emission in Romanian that told «the story of an old couple, Ioan and Dochita, in Moldavia, Romania who lived in deep poverty, they decided to travel across Dniester to Russia and took along their two children, a girl and a boy. The boy enrolled in the red army, and the girl started working for the cooperative where she got a leading role. The old couple now live happily, they have money and food» (F. 153/1939-1940, pp. 238, 239, 242).

At the end of January 1940, the Council of Cooperation of Ismail District made of the prefect of the district and the representatives of the military, police, and judicial authorities of the district noted that in Ismail the newspaper «Izvestia» continued to be spread among the people and the communist propaganda continued more fiercely.

The communist propaganda was made especially in Chilia Noua region Neruşai - Cişmele. The information that «at the beginning of March the Russian will occupy Bessarabia» spread along. This propaganda of the communist agents "demoralized the people who decide to abandon cropping for the Russians not to get them" (F. 78/1940, pp. 277-278).

\section{The first days of the Soviet regime in Ismail District}

Even since the first day of invading Bassarabia, the Soviet authorities declared the existant administrative, judicial, military, and police organs as not legal. The activity of the political parties (apart from the communist one) were forbidden, and the unions were supressed. The functions of the Romanian administration were taken over by military comisariates and the political organs of the red army, and they took over the prerogatives for forming new local administrative organs (Petrencu, 2012: 109). 
In the Report of the Regional Police Inspectorate of July, 30 1940, on the chapter «The actual state of facts in the occupied territory, Cahul and Ismail, and the aspect of life under the new regime», it was told that immediately after the Soviet troops came, the Romanian institutions were occupied by the Soviet army, and the newly creted police and administrative organs recruted «Russian minoritary and others having communist adesion», and the «Romanian element started to be gathered and deported to unknown places in Russia» (F. 133/1940, p. 95; F. 153/1939-1940, p. 46). The reports of the competent authorities also noted that the Romanian administrative institutions were replaced by revolutionary committees that were created in all the villages of Ismail and Cahul districts from the very first hours of the Soviet invasion (F. 153/1939-1940, p. 65) and that some groups of armed civilians, especcially Jews, behave badly and brutally with the Romanian population that remained in Ismail, Reni, Bolgrad, Chilia Nouă și Vălcov (F. 92/1940, p. 377).

In Ismail, even since the morning of June, 281940 a group of aproximately 200 protesters, both men and women, was created out of the minority population of the town, especcially Jews. After several protests of adesion to the Soviet Union, they went to the firemen unit where they stopped the fire men from evacuating their equipment by saying that it belonged to the village. The prefect of Ismail, in order to reconcile a conflict that could get out pf proportion, ordered that the evacuation of the equipment for fire extinguish had to be stopped. Afterwards, the protesters went to the Police where they asked to be shown if communist were arrested. The commandment of the local police allowed a delegation of the protesters to visit the place in order to check thouroughly and as they did not find anything they left quietly the Police section. The former barracks of the Romania troops were also devasted (F. 92/1940, p. 377). On the night of 29 to 30 June 1940, the communist protesters in Ismail opened fire against the ship of refugees that was leaving the Ismail port (F. 133/1940, p. 98).

The manifestations in the streets went on and on, and they carried placards with the portraits of Stalin, Molotov, and Lenin. They were led by two men in red shirts 
in front of the communist protesters: Paladov și Gresin. Among the leaders of the protesters were also identified Mandel - former president of the Work Chamber, Poltorac - pharmacist, the famous communist Vasilian Niconov, and others (F. 92/1940, p. 377; F. 153/1939-1940, p. 44). On July, $2^{\text {nd }}$, the statue of King Ferdinand I in the center of Ismail was destroyed «by a group of protesters made up of Jews and Russians, yelling that they did not need the king and God» (F. 78/1940, p. 632; F. 133/1940, p. 103).

On the $5^{\text {th }}$ of July 1940 , the official welcome of the Russian army was organized according to Soviet tradition: the tribune adorned with the red flag and red flowers, and the portraits of the Soviet leaders. At the parade that took place in front of a Soviet general participated 2 artillery divisions, 2 cavalry divisions, 2 companies of trenchers, 4 companies of infantry, and 12 military airplanes. The army was lively hailed by the people. The general that organized the parade made a speech saying that: «You managed to get rid of the Romanian occupation, of poverty, we have no poverty, everybody has food to eat», and asked the workers to work and they will be given everything they need (F. 92/1940, p. 376; F. 133/1940, p. 103).

The new administrative authorities were created even since the first days of the Soviet regime. The mayor of Ismail, Alexandru Minov, who was designated on May, 281940 (F. 61/1940, p. 31) «tore the Romanian flag as soon as the exchange of authorities began, and walked over the portrait of the king, and flew the red flag. The revolutionary committee began to be also created. Despite al these, the following committee chose the Jew Iasa Leventov as mayor». Ivancenco - the director of the boys' highschool was chosen to be the prefect. Gherscovici Iosif, owner of the oil factory - representative at Continent Export, and they took over the post office. Crumschi, former cashier at tha bus society in Ismail took over the district phone calss. Doctor Bergher, Jew from Chilia, was chosen region comissisary. Leon Becher called Blum, reffugeed from Chilia Veche, former driver for General P. Angelescu, former Ministry, former owner of a boat became the captain of the port of Ismail (F. 92/1940, p. 377 verso).

The president of the Soviet committies in Ismail was Valerian Niconov, former 
clerk at the Ismail mayor house, involved in espionage for the Soviet regime, owner of a radio, but aquitted because he said that it belonged to his younger brother. The new administration of Ismail also included: brothers Poltarac - pharmacists, former members of the revolutionary committee in 1918-1923, Abraham Grinvald photographer, Ubștein - dentist, and his wife, N. Mendel - former president of the work chamber, S. Agramov, B. Naidinov, V. Stas, Gh. Mizichevici - former clerks at the Ismail mayor's. (F. 92/1940, p. 377).

The authorities of Ismail town broadcast a manifest in Russian that mentiond the following: «As citizens faithful to the great Soviet Union, we gratefully welcome our liberators, the red army, and for this we ask every citizen to have a correct attitude and the development of life in town to be led normally and in order» (F. 92/1940, pp. 377-377 verso; F. 133/1940, p. 98).

The village of king Ferdinand in Ismail that used to be called Nicolaevca was completely burnet down for the reson that in 1924 his inhabitants, German, opposed to the rebelion in Tatarbunar (F. 92/1940, p. 377 verso).

In Bolgrad, where on the morning of June, 29 the Soviet troops launched from airplanes blocked the trains with military and the refugees, a group of protesters acted, and they were led by lawyers Al. Bancov and Chițis, fisherman Al. Grișcenco and others. Upon the arrival of the Russian air troops, they involved in the activity at the train station and dedicated to the hostile protests against the Romanians, by throwing stones at the wagons of evacuated and disarming police men at the station. Afterwards, the protests started in Bolgrad, by flying the red flags on private houses and institutions, starting with the police office (F. 153/1939-1940, p. 45). The revolutionary committee in Bolgrad included: Camburov, former magistrate and former mayor of Bolgrad, Cristoforov - professor, former parliamentary in Agura; Bancov Șura (Alexe) - lawyer, Liuba Titorov - lawyer. This committess took over the administrative leding of Bolgrad town (F. 92/1940, p. 377 verso).

At Vilcov the local committee included: Chiriac Chesanov, Ivan Carasiev and Mișa Gavrilov, having the famous communist Natalia Ciornei as president. Here a group of communists tried to set hotel Tourist on fire, but they were not let and 
punished by the local community (F. 153/1939-1940, p. 45).

In Chilia Noua, the revolutionary committee included: Dr. Salachin - doctor, former parliamentery, who also used to lead Chilia, Neiborschi - former parliamentary and the Jew Rabinovici (F. 92/1940, p. 377 verso). The mayor's house in Chilia Noua village was led by 9 men and 9 women, all Russians, under the commandment of Vlasenco, former health agent in the village Cismele, Ismail (F. 133/1940, pp. 51, 303). The population of the village Chilia Noua proposed to the Soviet authorities that the former mayor of the village «should be shot because he oppressed the Romanians. The military leader told them that they could not and that he was to be sent to Siberia» (F. 133/1940, p. 303).

At Reni, on the morning of June, 29, the Jewish traders flew red flags on their shops, and groups of workers gathered in the city of the town, a part of them leaving to the Eastern end of the town, waiting for the Soviet troops. A group of Jews stood put at the passing end towards the river Prut, where challenged the population not to evacuate, and others went to the Police Office, and broke the deposits of the old archive that they tore and walked upon, and then flew a red flag above the building. Another group led by doctor A. Braunstein was formed, and it went through the villages around, attiring people to revolt and rob the rich. Among the leaders of the communist protesters at Reni A. Braunstein - doctor, Fridel Losac - lawyer, the members of Finchel family, Dora Iaroslavschi, Gheorghe Danoev and others were others (F. 153/1939-1940, pp. 44-45).

\section{The Installing of the Soviet regime}

Generally, the information about the situation that appeared in the first weeks of the Soviet regime was fragmentary, inconsistent, and episodic. According to the data contained by the reports of the official authorities, the gendarmerie, and the police, the first information come from Bessarabia resumed the following:

- The Russian border at Dniester was closed and no one was allowed to cross from Bessarabia to the Soviet Union unless they were checked before leaving (F. 78/1940, p. 631).

- The deserters of the Romanian army that the Soviet authorities caught were 
sent to Russia, at over $300 \mathrm{~km}$ from the Romanian border (F. 133/1940, p. 50).

- The Romanians on the Russian territory were forbidden to wear the red badges so that they would be differenciated from the locals. It was said that they were all arrested and sent to camps, with the intention to take them to Cetatea Alba to become workers in agriculture (F. 92/1940, p. 376).

- In towns, the «so called purification from the elements that endangered the new regime» was applied. All that used to be part of Romanian administration with little exceptions became the victims of this measure, the rich people, those denounced out of hate and for vengeance, and they were taken from their homes and kept in arrest not knowing what would happen to them (F. 153/1939-1940, p. 41).

- The measure that the clerks remained in Bessarabia should be sent in Russia as being replaced by Soviet clerks was taken (F. 78/1940, p. 631).

- Children aged from 7 to 14 started to be institutionalized in communist institutions (F. 153/1939-1940, p. 47).

- The industries that supplied with water and electricity did not function on a regular base because oil, gas, and fuel were saved (F. 78/1940, p. 631).

- In towns, the count of all private houses was made, and their owners only got the apartments that they lived in, the rest of the apartments and buildings that were given for rent and that they got money for were taken by the town committee, that would give them to people (F. 153/1939-1940, p. 41, 48). All the mobile and luxurious properties were confiscated from those who were considered to have too much, and they were left only with the bare necessities. The same was done regarding clothing (F. 78/1940, p. 631).

- Compulsory work was introduced for all, no matter their origin or social status, «including women who were forbidden to wear luxurious things, a uniform being established». In Chilia Noua, for instance, «the Suliman Ostrov dig was being repaired with people forced to work» (F. 78/1940, p. 631; F. 133/1940, pp. 95, 51).

- The poor people is fed with fish soup from cauldron, a meal a day (F. 153/1939-1940, p. 47). In Ismail, eating houses were opened where free tea and flour were given to the poor workers (F. 92/1940, p. 376). 
- On the market Romanian money were still used, but food got more expensive. Aliments were so expensive that one kilo of bread was above 50 lei, and the workers were paid on bonds, and not money in order to get food from the deposits. The aliments that were not considered to be first necesities were exageratedly priced so a kilo of bacon was 400 lei (F. 78/1940, pp. 631, 632; F. 133/1940, p. 50).

- Pieces of clothing, stuff, any kind of cloth were greedily bought by the officers of the Soviet army, and the soldiers of the red army were left to get watches and blades for shaving that were very much sought. So, the shops theta ere let to trade eventually closed because they were left empty (F. 153/1939-1940, p. 41). Starting July, 12, all the existent shops were closed and the goods in the deposits were confiscated by the authorities (F. 133/1940, pp. 50, 51, 95, 303; F. 153/1939-1940, p. 46).

- All the bars were closed and «alchohol was no longer served because the population even from the beginning of the evacuation got drunk and did bad deeds» (F. 133/1940, p. 95; F. 153/1939-1940, p. 47), and «those who do not respect this are punished to death» (F. 92/1940, p. 376).

- The locals of Chilia Noua complained to some Russian Colonel that the Romanian state took big taxes, brought into requisition their horses and wagons, and that they were oppressed by the Romanian authorities, and he answered: «As far as I can see you lived well under the Romanians, the town of Chilia Noua has plenty of stuff and goods, paved streets, electricity, beautiful houses; they brought into requisition your wagons and horses was in the interest of the country, and we shall do this, as well». (F. 133/1940, p. 51).

- Cereals are no longer sold on the market. All the cereal stocks were confiscated, and the people were left only with the bare necessities. At the countryside, people were discontent about this, especially as the new crop was being obtained under the surveillance of the Russian authorities that confiscated all the available quantities without repaying the producers. The Romanian authorities thought that «the measure is taken by the red army that had big units all over the Southern Bessarabia, as they needed to feed their military and horses» (F. 133/1940, 
p. 50, 303; F. 153/1939-1940, p. 47).

Regarding the reform in agriculture, the Soviet authorities made propaganda in order to gain the rural population in their side, they said that the lands would not be confiscated by the state, but would be shared to the poor ones, so that no housekeeping had less than 30 ha. They even disposed that lands over 30 ha should be given to the poor peasants with all the necessary signatures from the former land lords, so that the new masters could get their crops starting that year. In fact, the Romanian authorities thought that the actions taken by the Soviet authorities were but «propagandistic actions following a double purpose, the new leaders came to help the poor working class in order to attach it to the Soviet regime, and to satisfy for the moment the aspirations of the social class that the new administration could count on in the future, so that peace and order could be maintained by avoiding reactions from the people used for aged to be owners». Yet, «those who made propaganda for the new communist regime who developed certain actions in towns, in meetings and other ways, according to official directives, did not try to hide that the actual state of things would not remain for long, and that the private property would soon be gone, and the entire system would be collective» (F. 153/1939-1940, pp. 39, 47).

\section{The attitude of the Soviet regime towards the church}

In the first days of the Soviet occupation the clerks of the church also had to suffer. The churches were turned into caserns, ball rooms, horse barns, and deposits. In Ismail, one of the churches was turned into a car garage; St Dumitru church was turned into a potato deposit, the monastery built in the autumn of 1938 became a barrack, and the monk monastery - a horse barn. The crosses were taken from all the churches. The adornments of all the churches were confiscated, the sacred paintings destroyed (F. 78/1940, p. 632; F. 92/1940, p. 376; F. 133/1940, p. 50). More Russian soldiers entered the monastery Borisovca in Ismail who dishonoured the nuns, destroyed the sacred paintings, and the church adornments. On July, $2^{\text {nd }}$, priests Mocanu and Ursu were shot and then taken into the streets (F. 92/1940, p. 377 verso, 406). 
On July, 71940 the Russians Lippovans of Ismail wanted to make religious services in their churches, but they were stopped by the Soviet authorities. Some of them complained to the Russians in Tulcea who carried refigies and they regretted the Romanian administration that respected their religion (F. 92/1940, p. 298; F. 133/1940, p. 103).

\section{The military Soviet system in the South of Bassarabia}

According to the data contained by the report of the Regional Police Inspectorate of Dunarea de Jos, Galati for the interval between June, 27 and July, 4 1940 , the first information having a military character from Bassarabia ware as it follows:

«The airport of Ismail was enlerged with several ha, and it became a strong aviation center.

Near Chilia Veche there are Soviet boats that check upon the Danube river, and over night they come near the Romanian shore as well, making checks.

In Ismail on the July, 5 and 6 a lot of Soviet army came and several ships on the Danube, the people greeting them and welcoming them. Also in Ismail big airplanes arrived loaded with up to 1 oo soldiers, all the town of Usmail following to become an important military center» (F. 78/1940, p. 632).

In June, the Soviet authorities took several series of measures regarding the consolidation of the military regime at the bottom of river Danube. According to the data presented by the informative notes of the Royal Resident of the Dunarea de Jos region, the bulletins of Regiment 3 Gendarmerie of Dunarea de Jos and the reports of the Regional Police Inspectorate of Dunarea de Jos in July 1940 a massive concentration of military force took place and the military buildings were consolidated. In the districts Tighina, Cetatea Albă and Ismail, the red army composed of artillery units, cavalry units, and tanks installed in almost all the main towns. Their equipment could not be estimated. The works to fortify the region from Nerușai to Bolgrad and Baimaclia were considered very important (F. 153/19391940, pp. 40, 48).

The following situation was created in Ismail district: 
- In Ismail the military Soviet headquartrs disrupted at the Industrial Girl Highschool, the border guards headquarters - at the House of the Hydraulic Services in the port (F. 92/1940, p. 377).

The airport built by the Romanian authorities concentrated importance Soviet force. Here a squadron of airplanes that flew daily in order to practice was disrupted. Two of the airplanes were used as postal airplanes, and they flew daily from Ismail to Odessa and backwards (F. 133/1940, pp. 51, 103).

In Sofiana village that was located at $9 \mathrm{~km}$ North from the town of Ismail the Soviet authorities started to lay the land flat in order to build a new airport, that shows that the red army would have its main base here reuniting the air forces in the South of Bessarabia. The land on which the new airport was being built was situated at the North East from Sofiana, a village connected by a stone street to the town of Ismail, and it was built by the Romanian administration (F. 153/1939-1940, pp. 40$41,48)$.

In Ismail port, frequent movements of war ships were noticed. On the $3^{\text {rd }} \mathrm{f}$ July, at $8 \mathrm{PM}, 2$ war ships (part of the Soviet navy) arrived in Ismail port, and one of them remained, and the other left for Vilcov. On the night of 15 to 16 July, three Soviet monitors came around 1:30 without speed, noise or light, and stopped at km 46-47, on a spot where they probably landed ammunition and arms. On the night of 20 to 21 July, from Chilia Veche to Vilcov a lot of Soviet war ships navigated on the Danube River. Soviet war ships entered the Chilia channel. Where Chilia goes into the sea, Russian mine sweepers arrived to dig continuously the channel towards the sea. No incidents were recorded on the Danube River between the Romanian and the Russian armies. (F. 92/1940, pp. 376, 377; F. 133/1940, pp. 103, 104).

- In Chilia Noua 4 regiments were disrupted: of infantry, cavalry, artillery, and motorized. From Caramehmet new infantry troops and 40 cars came to Chilia Noua. A lot of cars, tanks, and motorized cannons were installed in the North East at 400 $m$ from Chilia Noua. On the same day, a squad of chivalry arrived. The soldiers lived in tents and their guns are headed at Chilia Noua (F. 133/1940, p. 104).

At the the Lipovan church of Chilia Noua 15 big cannons were installed, and 
at the woof factory on the Danube shore -5 cannons hidden by wood boards. Around 30 tanks were left in Chilia Noua, the rest left for Ismail. The shops in Chilia Noua are full of ammunition. Observation posts were installed at the factories on the Danube shore and the Russian church in Chilia Noua on Stefan cel Mare Street. On the Danube shore, East town, they worked day and night at digging trenches. (F. 133/1940, pp. 103-104).

- At Vilcov 3 ships and 3 trackers arrived; the ships are loaded with ammunition (guns, machine guns, bullets, and grenades), and in Bolgrad 105 airplanes that bring paratroopers from Russia daily were found. (F. 133/1940, p. 51).

- At Reni the Russian troops are hidden inside vineyards where they have their machine guns and guns installed, and at the margin of the town behind the barracks they have tanks. On the Danube shores the Soviet guards are installed from 50 to 50 meters, and exchanges are made on trucks (F. 133/1940, p. 303).

We mention that per total on the occupied territory the Soviet Union had 15 divisions of motorized infantry and chivalry, 7 brigades of tanks and air troops (Gribincea, 1995: 17).

One of the tasks of the Soviet troops was to collect information about the Romanian troops nearby on the a possible future attack in the South West. On July, 6, 7 PM, the locals Demente Parahovenco and Vlase Constantin, both from the suburbs King carol in Tulcea district went ashore with refugees in Ismail, and were taken afterwards by the Soviet army to the headquarters where they were kept for almost 2 hours and interogated on the military troops in Tulcea and the Danube Delta. All the boatmen in Lascar Catargi village who carried refugees to ismail on the $18^{\text {th }}$ of July 1940 were retained and taken to the military Soviet headquarters where they were asked about the military units in the area and aftrewards let go. (F. 133/1940, p. 103).

Cases of espionage were signalled. In July Ioan Istrate and Anghelov Gheorghe entered Romania unauthorized, both coming from Bessarabia on special missions of espionage for the Soviet army. Ioan Istrate confessed that he was sent on a special mission by the Soviet organs to gather data on the military troops in Buzau region, 
and he was given 7.000 lei for this mission. On the purpose, he was instructed several times on the way how he should operate in Buzau in order to get the information (F. 133/1940, p. 100).

It was noticed that in the military environment, the Russians talked about a possible attack in the South West and that they «would occupy Galati and Constanta up to Cernavoda». More locals confirmed that many Soviet soldiers told them that their purpose was to reach for Constanta asking what the distance up to there was (F. 92/1940, p. 377; F. 133/1940, pp. 103, 303).

On the fact that the danger of a possible Soviet invation was real the Royal Resident of Dunarea de Jos noted in note no. 1304 of the $29^{\text {th }}$ of August 1940, addressed to the home secretary where it was said that the information detained at that moment «in Bessarabia were 10 army units with tanks and airplanes, and that the Soviet army intended to attack us on the first decade of September of the year.» (F. 133/1940, p. 352).

\section{Conclusions}

Along with the retreat from Bessarabia an informational void was created in the relationship to the abandoned territory. The public authorities, the police organs and those of the gendarmerie gathered in the first weeks after the retreat information from the remitted military and civil. The respective information is marked by a certain doze of subjectivity and depends on the personal and professional qualities of those who gave them.

But these pieces of fragmentary information contained by the documents elaborated by the police organs, the gendarmerie, and the Royal Resident of the County Dunarea de Jos also allow a re-enactment of the events that took place in South Bessarabia during the retreat of the Romanian administration and the invasion of the Soviet troops.

Generally, during the retreat, the public clerks, the military troops and the civil population confronted two big oppositions: the abuses committed by the Soviet troops and the hostile attitude of the minority population. These two forces that acted constantly maltreated Romanian civil and military, and also provoked material loss. 


\section{Immediately after the invasion in the Ismail district, the Soviet authorities took}

strong measures to suppress everything that was Romanian and install the principles, the values, and the institutions that corresponded to the new regime.

\section{References}

Cașu Igor Ocuparea Basarabiei și Bucovinei de Nord de către Armata Roșie, 28-29 iunie 1940. Noi detalii din arhiva poliţiei politice sovietice din Kiev [Occupation of Bessarabia and Northern Bukovina by the Red Army, June 28-29, 1940. New details from the archive of the Soviet political police in Kiev] // 28 iunie 1940. Noi perspective asupra unei tragedii românești. Paris, 2018, pp. 9-17. [in Romania]

Gribincea Mihai Basarabia în primii ani de ocupație sovietică (1944-1950) [Bessarabia in the first years of Soviet occupation (1944-1950)]. - Cluj-Napoca: Dacia, 1995. 187 p. [in Romania]

Legea administrativă din 14 august 1938. Publicată în Monitorul Oficial al României nr. 187din 1 august 1938, pp. 3772-3801 [Administrative law of August 14, 1938. Published in the Official Monitor of Romania no. 187 of August 1, 1938, pp. 3772-3801]. [in Romania]

Pactul Ribbentrop-Molotov şi consecinţele lui pentru Basarabia. Culegere de documente [The RibbentropMolotov Pact and its consequences for Bessarabia. Document collection]. Chisinau: Universitas, 1991. 122 p. [in Moldova]

Petrencu Anatol Raptul Basarabiei, Nordului Bucovinei, Ţinutului Herţa. Prima ocupaţie sovietică (1940-1941) [Theft of Bessarabia, North of Bukovina, Herţa County. The first Soviet occupation (1940-1941)] // Limba Română, nr. 5-6 (204), 2012, pp. 106-117. [in Romania]

Şișcanu Ion Basarabia în contextul relaţiilor sovieto-române. 1940 [Bessarabia in the context of SovietRomanian relations. 1940.]. - Chișinău: Civitas, 2007. - 275 p. [in Moldova]

The Galaţi County Service of the National Archives, Fund 47, File no. 153/1939 (F. 153/1939). [in Romania]

The Galaţi County Service of the National Archives, Fund 47, File no. 61/1940 (F. 61/1940). [in Romania]

The Galaţi County Service of the National Archives, Fund 47, File no. 78/1940 (F. 78/1940). [in Romania]

The Galaţi County Service of the National Archives, Fund 47, File no. 88/1940 (F. 88/1940). [in Romania]

The Galaţi County Service of the National Archives, Fund 47, File no. 92/1940 (F. 92/1940). [in Romania]

The Galaţi County Service of the National Archives, Fund 47, File no. 133/1940 (F. 133/1940). [in Romania] 